\title{
KALIMAT EFEKTIF PADA PIDATO PERTAMA GUBERNUR DKI JAKARTA PERIODE 2017-2022, ANIES RASYID BASWEDAN
}

\author{
Ahmad Khoiril Anam \\ Program Studi Pendidikan Bahasa dan Sastra Indonesia, \\ Fakultas Bahasa dan Seni, Universitas Indraprasta PGRI \\ chairilanam45@gmail.com
}

\begin{abstract}
Abstrak
Penelitian ini membahas masalah penggunaan bahasa Indonesia, khususnya penggunaan kalimat efektif dalam pidato pertama Gubernur DKI Jakarta periode 2017-2022. Metode yang digunakan dalam penelitian ini adalah metode analisis deskriptif yang menjadikan teks pidato pertama Gubernur DKI Jakarta periode 2017—2022 sebagai objek kajiannya. Sampel yang digunakan dalam penelitian ini adalah keseluruhan isi dari teks pidato tersebut. Hasil kajian menunjukan bahwa dari 97 kalimat yang terdapat dalam teks pidato tersebut terdapat 61 kalimat efektif, jika dipersentasekan mencapai 62,89\%. Di samping itu, kalimat tidak efektif sejumlah 36 kalimat atau 37,11\%. Dari 36 kalimat tersebut, di antaranya 7 atau $7,21 \%$ kalimat tidak sepadan, 3 atau 3,1\% kalimat tidak paralel, 16 atau 16,49\% tidak hemat, 7 atau $7,21 \%$ kalimat tidak padu, dan 3 atau 3,1\% kalimat tidak logis. Atas hasil tersebut, penulis menyimpulkan bahwa penggunaan kalimat pada pidato pertama Gubernur DKI Jakarta terpilih, periode 2017-2022, Anies Rasyid Baswedan cenderung efektif.
\end{abstract}

Kata Kunci: kalimat efektif, pidato, Gubernur DKI Jakarta

\begin{abstract}
This study discusses the use of Indonesian language, especially the use of effective sentence in the first speech of Jakarta Governor 2017-2022 period. The method used in this research is descriptive analysis method that makes the first speech text of Jakarta Capital City period 2017-2022 as the object of study. The sample used in this study is the entire contents of the text of the speech. The results of the study show that of the 97 sentences contained in the speech text there are 61 effective sentences, if the percentage reached $62.89 \%$. In addition, the sentence is not effective in some 36 sentences or $37.11 \%$. Of the 36 sentences, of which 7 or $7.21 \%$ of sentences are not equivalent, 3 or $3.1 \%$ of sentences are not parallel, 16 or $16.49 \%$ are not sparing, 7 or $7.21 \%$ sentences are not solid, and 3 or $3,1 \%$ illogical sentence. On the results, the authors conclude that the use of sentences in the first speech of the Governor of DKI Jakarta elected, the period 2017-2022, Anies Rashid Baswedan tend to be effective.
\end{abstract}

Keyword: effective sentence, speech, Jakarta Governor

\section{PENDAHULUAN}

Bahasa merupakan sistem lambang bunyi yang berartikulasi, bersifat arbitrer, dan konvensional. Selain itu, bahasa digunakan oleh manusia sebagai alat komunikasi utama untuk menyampaikan perasaan, pikiran, dan pendapatnya. Oleh karena itu, eksistensi bahasa sangat penting dalam segala aspek kehidupan manusia. Termasuk dalam aspek pemerintahan dan politik.
Bahasa dan politik merupakan dua hal yang berbeda. Akan tetapi, keterkaitan antarkeduanya tidak dapat terelakan lagi.

Bahasa merupakan unsur terpenting dalam kehidupan manusia dalam berkomunikasi, sedangkan politik me-rupakan segala urusan, tindakan, dan kebijaksanaan mengenai pemerintahan atau ketatanegaraan. Pemerintahan atau ketatanegaraan tersebut diduduki oleh sekelompok 
manusia yang ber-kompenten di bidangnya. Untuk menyampaikan pikiran dan pendapat yang berkenaan dengan ketatanegaraan, manusia, dalam hal ini pemerintah, membutuhkan bahasa sebagai media utamanya. Oleh karena itu, hubungan antara bahasa dan politik tak terelakan lagi.

Politik di Indonesia dewasa ini diramaikan dengan pilkada serentak yang akan dilaksanakan pada tahun 2017 ini. Hampir seluruh daerah di Indonesia akan melaksanakan pilkada di tiap-tiap daerahnya. Dengan demikian pertarung-an-pertarungan politik antarcalon pe-mimpin-pemimpin daerah pun mulai memanasi dunia politik di negeri ini. Tak terkecuali dengan ibu kota negara, DKI Jakarta.

Pertarungan-pertarungan politik antarcalon pemimpin daerah tersebut menyebabkan kondisi politik Indonesia dewasa ini semakin memanas. Salah satu penyebabnya adalah penggunaan bahasa yang tergolong masih belum dikategori-kan baik dari sisi kesantunan maupun kaidah kebahasaan. Oleh karena itu, penggunaan bahasa Indonesia yang baik dan benar di kalangan politisi sangatlah penting.

Salah satu kaidah kebahasaan yang perlu dikaji lebih lanjut adalah perihal kalimat efektif. Kalimat efektif adalah kalimat yang apabila disampaikan oleh penulis atau pembicara dapat langsung memberikan efek maksimal kepada pembaca atau pendengarnya. Dalam hal ini apa yang hendak disampaikan oleh penulis atau pembicara tersampaikan oleh pembaca atau pendengarnya. Oleh karena itu, penggunaan kalimat efektif baik dalam bahasa tulis maupun lisan sangat penting bagi setiap orang, terutama pada kalangan politisi, lebih-lebih pimpinan daerah terpilih, agar pesan dari tiap-tiap politisi tersampaikan dengan baik.
Atas dasar tersebut tim peneliti tertarik untuk membahas sisi kebahasaan, dalam hal ini adalah penggunaan kalimat efektif yang digunakan oleh Gubernur DKI Jakarta terpilih, Anies Rasyid Baswedan, pada pidato pertamanya setelah beliau dilantik menjadi Gubernur DKI Jakarta yang baru. Fokus penelitian ini adalah penggunaan kalimat efektif pada pidato pertama Gubernur DKI Jakarta terpilih periode 2017-2022, Anies Rasyid Baswedan. Pidato Gubernur DKI Jakarta terpilih periode 2017-2022, Anies Rasyid Baswedan menjadi pilihan penulis karena perhatian masyarakat Indonesia kini tertuju pada orang nomor satu di ibu kota negara Indonesia tersebut. Dengan demikian, tim peneliti sepakat untuk menulis dengan judul Kalimat Efektif dalam Pidato Pertama Gubernur DKI Jakarta Terpilih Periode 20172022, Anies Rasyid Baswedan.

Arifin dan Tasai (2008: 66) mengungkapkan bahwa kalimat merupakan satuan bahasa terkecil, baik itu disampaikan dalam bahasa lisan maupun tulisan, yang isinya telah mengungkap-kan pikiran pesan yang utuh. Artinya, jika satuan bahasa itu belum membentuk sebuah kalimat, maka belum dapat menyampaikan sebuah pesan yang utuh. Selain itu, kalimat merupakan unsur bahasa yang terbentuk oleh beberapa kata minimum terdapat subjek dan predikat yang diakhiri dengan intonasi akhir dalam bahasa lisan dan tanda baca aknir dalam bahasa tulis. Dengan demikian, jika terdapat subjek dan predikat yang tidak diakhiri dengan intonasi akhir, hal itu ukan dikatagorikan sebagai kalimat melain masih dalam bentuk klausa. Sejalan dengan itu, Finoza dalam Dewi dkk. (2016: 77) menjelaskan bahwa kalimat merupakan bagian dari berbagai ujaran atau tulisan yang berstruktur minimum subjek dan predikat serta 
intonasi finalnya me-nunjukkan bahwa ujaran atau tulisan tersebut sudah lengkap dengan makna. Berdasarkan dua teori tersebut dapat disimpulkan bahwa kalimat merupakan satuan bahasa, baik berupa lisan maupun tulisan, yang terdiri dari sekurangkurangnya subjek dan predikat yang diakhiri dengan intonasi akhir, serta sudah menyampaikan pikiran yang utuh.

Arifin dan Tasai (2008:97) berpendapat Kalimat efektif adalah kalimat yang meberikan kembali gagasan kepada pendengar atau pembacanya seperti apa yang dipikirkan pembicara atau penulis-nya. Kalimat efektif sangat mengutama-kan keefektifan informasi sehingga kejelasan kalimat itu dapat terjamin. sejalan dengan itu, Sasangka (2016: 54) mengemukakan bahwa kalimat efektif adalah kalimat yang mampu me-nyampaikan gagasan atau ide sesuai dengan yang diharapkan oleh si penulis atau si pembicaranya. Artinya, kalimat yang dipilih penulis atau pembicara pun harus dapat digunakan untuk meng-ungkapkan gagasan, maksud atau informasi kepada orang lain secara efektif sehingga gagasan itu dipahami secara sama oleh pembaca atau pen-dengarnya. Di samping itu, Arifin dkk (2012: 83) menambahkan bahwa kalimat efektif adalah kalimat yang apabila disampaikan, baik secaralisan maupun tulisan, mampu memberikan efek atau pengaruh kepada pembacanya atau pendengarnya. Kalimat dikatakan berefektif jika dapat mengungkapkan sesuatu dengan jelas serta dapat mewakili gagasan atau pemikiran penulis secara tepat sehingga pendengar atau pembaca dapat memahami isi kalimat tersebut sesuai dengan yang dimaksudkan penulisnya. Selain itu, Gani (2014: 68) mengemukakan bahwa kalimat efektif adalah kalimat yang apabila dituturkan atau ditulis dapat mewakili ide pembicara atau penulis serta sanggup menyampaikan ide yang sama tepatnya dengan pikiran pendengar atau pembaca-nya. Berdasarkan pendapat di atas, penulis dapat menyimpulkan bahwa sebuah kalimat efektif akan mampu mewakili ide yang ada dalam benak pembicara atau penulis dan pendengar atau pembaca, tanpa menimbulkan salah paham. Sebagai penutup, Widjono (2012: 205) mengemukakan bahwa kalimat efektif merupakan kalimat yang singkat, jelas, lengkap, dan dapat menyampaikan informasi secara tepat kepada siapa pun yang membaca atau mendengarnya. Artinya, suatu kalimat dikatakan efektif jika kalimat tersebut hanya menggunakan unsur-unsur yang diperlukan saja, sarat akan makna, struktur kalimat dan makna yang terkandung jelas, dan mengandung kelengkapan struktur kalimat secara gramatikal sehingga kalimat tersebut dapat menyampaikan informasi secara tepat. Berdasarkan beberapa teori di atas, penulis dapat menyimpulkan bahwa kalimat efektif adalah kalimat yang apabila disampaikan oleh penulis atau penutur mampu memberikan efek, dampak, atau pengaruh kepada pembaca atau pendengarnya. Efek atau pengaruh yang dimaksud adalah jika kalimat tersebut dapat mengungkapkan sesuatu dengan jelas serta dapat mewakili gagasan atau pemikiran penulis atau pembicara secara tepat sehingga pendengar atau pembaca dapat memahami isi kalimat tersebut sesuai dengan yang dimaksudkan penulisnya.

Aririn dkk. (2017) menyebutkan bahwa sebuah kalimat efektif mempunyai ciri khas, yaitu kesepadanan struktur, keparalelan bentuk, ketegasan makna, kehematan kata, kecermatan penalaran, kepaduan gagasan, dan kelogisan bahasa. Kesepadanan dalam 
kalimat efektif adalah Keseimbangan antara pikiran (gagasan) dan struktur bahasa yang dipakai. Artinya mempunyai subjek dan predikat yang jelas, tidak terdapat subjek yang ganda, tidak menggunakan penghubung intrakalimat dalam kalimat tunggal, dan predikat kalimat tidak diduhului oleh kata yang. Keparalelan ditandai dengan kesamaan bentuk kata yang digunakan dalam kalimat itu. Artinya, jika bentuk pertama menggunakan verba aktif, bentuk kedua dan seterusnya juga harus menggunakan verba aktif dan sebagainya. Ketegasan makna dalam kalimat ditandai dengan suatu perlakuan penonjolan pada ide pokok kalimat. Dalam suatu kalimat ada ide yang perlu ditonjolkan. Kalimat itu memberi penekanan atau penegasan pada penonjolan itu. Kehematan adalah hemat dalam mempergunakan kata, frasa, atau menghilangkan bentuk lain yang dianggap tidak perlu. Hemat berarti tidak harus menghilangkan katakata yang dapat menambah kejelasan kalimat. Penghematan dalam hal ini berarti penghematan terhadap kata-kata yang memang tidak diperlukan, sejauh tidak menyalahi aturan kebahasaan. Kecermatan adalah ketika kalimat itu tidak menimbulkan tafsiran ganda, dan tepat pada pilihan kata. Kepaduan adalah kepaduan pernyataan dalam kalimat sehingga informasi yang disampaikannya tidak terpecah-pecah. Yang dimaksud dengan kelogisan ialah bahwa ide kalimat itu dapat diterima oleh akal dan penulisannya sesuai dengan kaidah yang berlaku.

Kalimat efektif sangat dibutuhkan saat berkomunikasi, baik komunikasi dalam bentuk lisan maupun tulisan. Sugono (2009: 16) menyatakan bahwa ragam bahasa lisan merupakan ragam bahasa yang dihasilkan dengan menggunakan artikulator dengan fonem sebagai unsur dasarnya, sedangkan ragam bahasa tulis merupakan ragam bahasa yang dihasilkan dengan memanfaatkan tulisan dan huruf sebagai unsur dasarnya. Dari dua jenis ragam bahasa di atas, ada satu contoh ragam bahasa tulis yang biasa dibacakan sehingga terkesan termasuk ke dalam bahasa lisan. Contoh dari kasus tersebut adalah teks pidato yang dibacakan. Jenis ini termasuk ke dalam ragam bahasa yang unik karena termasuk ke dalam dua ragam bahasa tersebut. Oleh karena itu, kajian yang memuat teks pidato patut untuk dilakukan lebih lanjut. Karomani (2011: 12) mengutarakan bahwa pidato umumnya ditujukan khalayak dengan tujuan yang berbeda-beda, di antaranya adalah untuk menyatakan selamat, menyambut kedatangan tamu, mem-peringati harihari besar, dan lain sebagainya. Selain itu, Tarigan (1997:73) menyatakan bahwa aktivitas berpidato adalah kegiatan berbicara di hadapan orang banyak atau di depan umum dalam rangka menyampaikan suatu topik untuk mencapai suatu tujuan tertentu, misalnya untuk bermusyawarah, memberikan rujukan dan sebagainya.

\section{METODE PENELITIAN}

Pendekatan penelitian ini bertumpu pada pendekatan kualitatif yang menekankan pada penggunaan kalimat efektif pada naskah pidato pertama Gubernur DKI Jakarta terpilih periode 2017-2022, Anies Rasyid Baswedan. Data yang digunakan dalam penelitian ini adalah naskah pidato Gubernur DKI Jakarta terpilih periode 2017-2022 tersebut. Teknik sampiling pada penelitian ini adalah teknik sampling jenuh, yaitu menjadikan populasi menjadi sampelnya. Dengan demikian, populasi dan juga sampel pada penelitian ini adalah naskah pidato Gubernur DKI Jakarta terpilih periode 
2017-2022 tersebut.Metode yang digunakan dalam penelitian ini adalah metode deskriptif atau analisis isi (content analysis). Sampel yang digunakan adalah naskah pidato pertama Gubernur DKI Jakarta terpilih periode 2017-2022, Anies Rasyid Baswedan. Peneliti dalam penelitian ini berkedudukan sebagai instrument utama dan dibantu oleh tabel analisis data. Model atau instrumen yang digunakan dalam penelitian ini adalah dengan menganalisis data atau naskah pidato terkait yang dibantu oleh tabel analisis data. Dengan ini, peneliti akan lebih mudah menganalisis dari tiap-tiap kalimatnya.

\section{HASIL DAN PEMBAHASAN}

Dalam artikel ini, penulis memaparkan hasil penelitian kalimat efektif pada teks pidato pertama Gubernur DKI Jakarta terpilih periode 2017-2022, Anies Rasyid Baswedan. Teks pidato tersebut dipilih penulis sebagai objek kajian karena merupakan hal yang penting dalam dunia kebahasaan, khususnya di ranah politik tanah air. Oleh karena itu, kajian tersebut perlu dilakukan, terutama dalam aspek kalimat efektif. Di bawah ini merupakan hasil dari kajian kalimat efektif dalam teks pidato pertama Gubernur DKI Jakarta terpilih periode 2017-2022, Anies Rasyid Baswedan.

Diagram 1

Hasil Analisis Kalimat Efektif dan Kalimat Tidak Efektif Gubernur DKI Jakarta Terpilih Periode 2017 - 2022, Anies Rasyid Baswedan

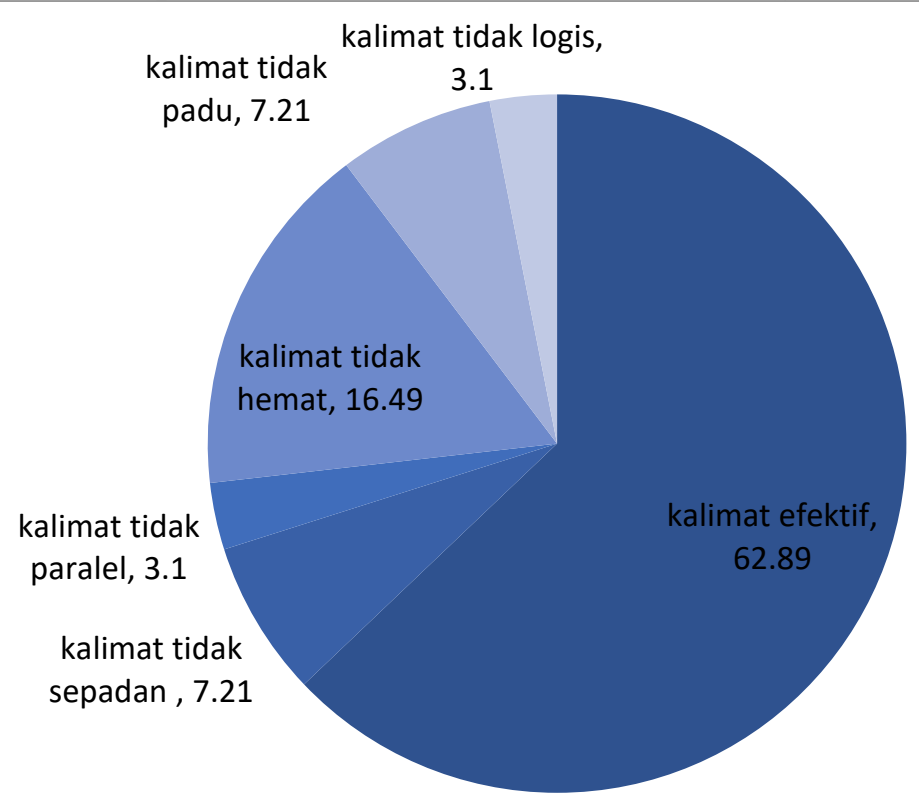

Berdasarkan diagram di atas, dapat penulis jelaskan bahwa jumlah kalimat yang terdapat dalam teks pidato pertama Gubernur DKI Jakarta terpilih, periode 2017-2022, Anies Rasyid Baswedan, terdapat 97 kalimat. Hasil kajian menunjukan 61 kalimat efektif, jika dipersentasekan mencapai $62,89 \%$. Di samping itu, kalimat tidak efektif sejumlah 36 kalimat atau 37,11\%. Dari 36 kalimat tersebut, di antaranya 7 atau 7,21\% kalimat tidak sepadan, 3 atau 
$3,1 \%$ kalimat tidak paralel, 16 atau $16,49 \%$ tidak hemat, 7 atau $7,21 \%$ kalimat tidak padu, dan 3 atau 3,1\% kalimat tidak logis. Atas hasil tersebut, penulis menyimpulkan bahwa penggunaan kalimat pada pidato pertama Gubernur DKI Jakarta terpilih, periode 2017-2022, Anies Rasyid Baswedan cenderung efektif. Berikut merupakan uraian beberapa hasil temuan kalimat tidak efektif pada naskah pidato tersebut.

\section{Kalimat Tidak Sepadan}

\section{Contoh:}

1. Kalimat kelima puluh pada pidato pertama Gubernur DKI Jakarta terpilih, periode 2017-2022, Anies Rasyid Baswedan

"Dalam kesepakatan berdasar musyawarah itu terkandung tuah kebermanfaatan."

Kalimat tersebut dinyatakan tidak sepadan karena terdapat kata dalam pada awal kalimat tersebut. Kata dalam boleh digunakan apabila berfungsi sebagai keterangan. Akan tetapi, dalam kalimat tersebut, kata dalam tidak berfungsi sebagai penanda keterangan, tetapi sebagai pengiring subjek. Jika kata dalam dirangkai sebelum subjek, subjek tersebut akanberubah fungsi menjadi keterangan sehingga subjeknya tidak ada. Dengan demikian, kata dalam yang mendahului subjek kalimat tersebut menjadikan kalimat tersebut tidak efektif karena menyebabkan hilangnya subjek. Kalimat tersebut dapat diperbaiki menjadi kalimat efektif seperti di bawah ini.

"Kesepakatan berdasar musyawarah itu terkandung tuah kebermanfaatan."

2. Kalimat ke-52 pada pidato pertama Gubernur DKI Jakarta terpilih, periode 2017-2022, Anies Rasyid Baswedan

"Karena hadirnya keadilan sosial ini akan menjadi parameter utama terwujudnya semangat Pancasila di kota ini"

Kalimat tersebut dinyatakan tidak sepadan karena terdapat kata karena pada awal kalimat tersebut. Kata karena boleh digunakan apabila berfungsi sebagai anak kalimat dalam kalimat majemuk bertingkat. Akan tetapi, dalam kalimat tersebut, kata karena tidak berfungsi sebagai penanda anak kalimat, tetapi sebagai pengiring subjek pada kalimat tunggal. Jika kata karena dirangkai sebelum subjek pada kalimat tunggal, kalimat tersebut akan berubah fungsi menjadi anak kalimat sehingga membutuhkan induk kalimat, sedangkan kalimat itu hanya ada satu klausa. Dengan demikian, kata karena yang mendahului subjek kalimat tersebut menjadikan kalimat tersebut tidak efektif karena menyebabkan kalimat tersebut menjadi menggantung dari segi makna.Kalimat tersebut dapat diperbaiki menjadi kalimat efektif seperti di bawah ini.

"Hadirnya keadilan sosial ini akan menjadi parameter utama terwujudnya semangat Pancasila di kota ini”

\section{Kalimat Tidak Paralel}

Contoh

1. Kalimat ke-43 pada pidato pertama Gubernur DKI Jakarta terpilih, periode 2017-2022, Anies Rasyid Baswedan

"Prinsip ketuhanan ini kemudian harus diwujudkan pula dengan hadirnya rasa kemanusiaan dan keadilan bagi seluruh rakyat, tanpa ada yang 
terpinggirkan, terugikan, apalagi tidak dimanusiakan dalam kehidupannya"

Kalimat di atas dinyatakan tidak efektif karena tidak adanya keparalelan bentuk. Dikatakan tidak paralel karena ada ketidaksamaan antara bentuk-bentuk pembentukan kata yang di sajikan. Ketidaksaam bentuk tersebut terlihat pada kata terpinggirkan, terugikan, dan tidak dimanusiakan. Kata terpinggirkan, terugikan, dan tidak dimanusiakan memiliki bentuk yang tidak paralel. Jika ingin disamakan, kata-kata tersebut dapat menjadi tidak pentingkan, tidak diuntungkan, dan tidak dimanusiakan. Dengan perubahan tersebut, maka menjadikan kalimat tersebut lebih efektif. Kalimat tersebut dapat diperbaiki menjadi kalimat efektif seperti di bawah ini.

"Prinsip ketuhanan ini
kemudian harus diwujudkan
pula dengan hadirnya rasa
kemanusiaan dan keadilan bagi
seluruh rakyat, tanpa ada yang
tidak pentingkan, tidak
diuntungkan, apalagitidak
dimanusiakan
kehidupannya"

2. Kalimat ke-46 pada pidato pertama Gubernur DKI Jakarta terpilih, periode 2017-2022, Anies Rasyid Baswedan "Persatuan dan keguyuban ini
yang harus terus kita
perjuangkan, dimulai dari
meruntuhkan
interaksi antar sekat-sekat
masyarakatnya, segmen
pemisahan ruang interaksi berdasar kemampuan ekonomi"

Kalimat di atas dinyatakan tidak efektif karena tidak adanya keparalelan bentuk. Dikatakan tidak paralel karena ada ketidaksamaan antara bentuk-bentuk pembentukan kata yang di sajikan. Ketidaksaam bentuk tersebut terlihat pada kata perjuangkan, meruntuhkan, dan pemisahan. Kata perjuangkan, meruntuhkan, dan pemisahan memiliki bentuk yang tidak paralel. Jika ingin disamakan, kata-kata tersebut dapat menjadi perjuangkan, peruntuhan, dan pemisahan. Dengan perubahan tersebut, maka menjadikan kalimat tersebut lebih efektif. Kalimat tersebut dapat diperbaiki menjadi kalimat efektif seperti di bawah ini.

"Persatuan dan keguyuban ini
yang harus terus kita
perjuangkan, dimulai dari
peruntuhan sekat-sekat interaksi
antar segmen masyarakatnya,
terutama pemisahan ruang
interaksi berdasar kemampuan
ekonomi"

\section{Kalimat Tidak Hemat}

Contoh

1. Kalimat ketiga pada pidato pertama Gubernur DKI Jakarta terpilih, periode 2017-2022, Anies Rasyid Baswedan

\section{"Assalamualaikum \\ Warahmatullahi Wabarakatuh. Salam sejahtera. Om swastiastu. Namo buddhaya."}

Kalimat di atas dinyatakan tidak efektif karena tidak memenuhi unsure kehematan. Dikatakan tidak hemat karena terdapat penggunaan kata yang tidak diperlukan. Tidak adanya kata tersebut pun tidak akan mengurangi atau mengubah makna kalimat yang bersangkutan. Ketidakhematan kata tersebut terlihat pada penggunaan kata Assalamualaikum Warahmatullahi Wabarakatuh, Salam sejahtera, Om swastiastu, dan Namo buddhaya secara bersamaan. Kata 
Assalamualaikum Warahmatullahi Wabarakatuh, Salam sejahtera, Om swastiastu,dan Namo buddhaya memiliki fungsi yang sama. Jika ingin dihematkan, kata-kata tersebut dapat diwakili oleh salah satunya, yaitu frasaSalam sejahtera. Dengan itu, maka menjadikan kalimat tersebut lebih efektif. Kalimat tersebut dapat diperbaiki menjadi kalimat efektif seperti di bawah ini.

"Salam sejahtera untuk kita."

2. Kalimat keempat pada pidato pertama Gubernur DKI Jakarta terpilih, periode 2017-2022, Anies Rasyid Baswedan

"Saudara-saudara semua, hari ini satu lembar baru kembali terbuka dalam perjalanan panjang Jakarta."

Kalimat di atas dinyatakan tidak efektif karena tidak memenuhi unsur kehematan. Dikatakan tidak hemat karena terdapat penggunaan kata yang tidak diperlukan. Tidak adanya kata tersebut pun tidak akan mengurangi atau mengubah makna kalimat yang bersangkutan. Ketidakhematan kata tersebut terlihat pada penggunaan kata Saudara-saudara semuasecara bersamaan. Kata Saudara-saudara semua memiliki fungsi yang sama, yaitu kata jamak. Jika ingin dihematkan, kata-kata tersebut dapat diwakili oleh salah satunya, yaitu kata ulangSudara-saudara atau saudara semua. Dengan itu, maka menjadikan kalimat tersebut lebih efektif. Kalimat tersebut dapat diperbaiki menjadi kalimat efektif seperti di bawah ini.

"Saudara-saudara, hari ini satu lembar baru kembali terbuka dalam perjalanan panjang Jakarta." atau "Saudara semua, hari ini satu lembar baru kembali terbuka dalam
perjalanan panjang Jakarta."

\section{Kalimat Tidak Padu}

Contoh

1. Kalimat ke-69 pada pidato pertama Gubernur DKI Jakarta terpilih, periode 2017-2022, Anies Rasyid Baswedan

"Bang Sandi sudah jabarkan bagaimana kita akan bersamasama membangun dan mengelola kampung, jalan, sekolah, puskesmas, pasar, angkot, dan berbagai aspek kota lainnya."

Kalimat di atas dinyatakan tidak efektif karena tidak memenuhi unsur kepaduan. Dikatakan tidak padu karena pola aspek dan agen tidak disusun secara tertib pada kalimat pasif perona. Kalimat tersebut dikategorikan pasif persona karena terdapat pola aspek sudah dan penanggalan imbuhan mengpada kata jabarkan sehingga tergolong kalimat pasif persona. Kalimat pasif persona harus disusun dengan tertib dengan mendahului pola aspek dan diikuti agen. Pola aspek tesebut adalah kata sudah dan agennya adalah Bang Sandi. Dengan itu, maka menjadikan kalimat tersebut lebih efektif. Kalimat tersebut dapat diperbaiki menjadi kalimat efektif seperti di bawah ini.

"Sudah Bang Sandi jabarkan bagaimana kita akan bersamasama membangun dan mengelola kampung, jalan, sekolah, puskesmas, pasar, angkot, dan berbagai aspek kota lainnya."

2. Kalimat ke-67 pada pidato pertama Gubernur DKI Jakarta terpilih, periode 2017-2022, Anies Rasyid Baswedan 
"Namun jelas pula bahwa kami hadir dengan tekad mengutamakan pembelaan yang nyata kepada mereka yang selama ini tak mampu membela diri sendiri, membantu mengangkat mereka yang selama ini terhambat dalam perjuangan mengangkat diri sendiri."

Kalimat di atas dinyatakan tidak efektif karena tidak memenuhi unsur kepaduan. Dikatakan tidak padu karena kalimat disajikan dalam bentuk yang bertela-tele sehingga menyebabkan pendengar atau pembacanya kesulitan memaknai pesan dari penuturnya. Oleh karena itu, perlu adanya perampingan kalimat yang disesuaikan dengan pesan inti dari kalimat tersebut. Dengan itu, maka menjadikan kalimat tersebut lebih efektif. Kalimat tersebut dapat diperbaiki menjadi kalimat efektif seperti di bawah ini.

"Namun, kami hadir dengan tekad untuk membela mereka yang tak mampu membela diri sendiri, mengangkat mereka yang dalam perjuangan mengangkat diri sendiri."

\section{Kalimat Tidak Logis}

Contoh

1. Kalimat ke-65 pada pidato pertama Gubernur DKI Jakarta terpilih, periode 2017-2022, Anies Rasyid Baswedan

"Jakarta harus maju bersama."

Kalimat di atas dinyatakan tidak efektif karena tidak memenuhi unsur kelogisan. Dikatakan tidak logis karena kalimat tersebut memuat diksi yang kurang tepat, baik secara logika, akal sehat, maupun kebiasaan. Kalimat di atas tidak sesuai dengan logika karena
kataJakarta tidak akan bisa maju. Jakarta akan tetap pada posisi yang sama dan tidak akan maju ke posisi yang lebih ke dapan. Jika ingin diubah lebih logis, dapat diubah menjadi perekonomian Kota Jakarta atau yang lainnya. Dengan itu, maka menjadikan kalimat tersebut lebih efektif. Kalimat tersebut dapat diperbaiki menjadi kalimat efektif seperti di bawah ini.

"Perekonomian, peradaban, transportasi, dan prestasi Jakarta harus maju bersama."

2. Kalimat ke-81 pada pidato pertama Gubernur DKI Jakarta terpilih, periode 2017-2022, Anies Rasyid Baswedan

"Mohammad Husni Thamrin, seorang putra terbaik Jakarta pernah mengatakan, setiap pemerintah harus mendekati kemauan rakyat."

Kalimat di atas dinyatakan tidak efektif karena tidak memenuhi unsur kelogisan. Dikatakan tidak logis karena kalimat tersebut memuat diksi yang kurang tepat, baik secara logika, akal sehat, maupun kebiasaan. Kalimat di atas tidak sesuai dengan logika karena frasa kemauan rakyat tidak dapat didekati, tetapi dapat direalisasikan. Dengan itu, maka menjadikan kalimat tersebut lebih efektif. Kalimat tersebut dapat diperbaiki menjadi kalimat efektif seperti di bawah ini.

"Mohammad Husni Thamrin, seorang putra terbaik Jakarta pernah mengatakan, setiap pemerintah harus merealisasikan kemauan rakyat."

\section{SIMPULAN}

Pidato adalah aktivitas berbicara di hadapan orang banyak atau di depan 
umum dalam rangka menyampaikan suatu masalah untuk mencapai suatu tujuan tertentu, misalnya untuk bermusyawarah, memberikan rujukan dan sebagainya. Untuk dapat menyampaikan pesannya dengan maksimal, sesorang harus mampu menggunakan kalimat dengan baik. Salah satu cara untuk dapat menyampaikan pesan secara maksimal, sesorang harus mampu menggunakan kalimat efektif dengan baik. Kalimat efektif merupakan kalimat yang apabila disampaikan oleh pembicara atau penulis dapat memberikan efek atau pengaruh secara langsung kepada pendengar atau pembacanya, sehingga mereka memahami maksud dari pembicara atau penulis tersebut.

Hasil kajian penulis berkenaan dengan penggunaan kalimat efektif pada pidato pertama Gubernur DKI Jakarta terpilih, periode 2017-2022, Anies Rasyid Baswedan cenderung baik. Hal tersebut dibuktikan dengan hasil-hasil sebagai berikut. Terdapat 97 kalimat dalam pidato Gubernur DKI Jakarta terpilih tersebut. Hasil kajian menunjukan 61 kalimat efektif, jika dipersentasekan mencapai $62,89 \%$. Di samping itu, kalimat tidak efektif sejumlah 36 kalimat atau $37,11 \%$. Dari 36 kalimat tersebut, di antaranya 7 atau $7,21 \%$ kalimat tidak sepadan, 3 atau
3,1\% kalimat tidak paralel, 16 atau $16,49 \%$ tidak hemat, 7 atau $7,21 \%$ kalimat tidak padu, dan 3 atau 3,1\% kalimat tidak logis.

\section{DAFTAR PUSTAKA}

Arifin, E. Z. dan Tasai S. A. (2009). Cermat berbasa Indonesia. Jakarta: Akademika Pressindo.

Arifin, E. Z. dkk. (2017). Penyuntingan naskah. Tangerang: Pustaka Mandiri.

Gani, R. (2014). Suka berbahasa Indonesia. Jakarta: Gunung Persada Press Group.

Sasangka, S. S. T. W. (2016). Kalimat. Jakarta: Pusat Pembinaan.

Sugono, D. (2009). Mahir berbahasa Indonesia dengan benar. Jakarta: Gramedia Pustaka Utama.

Susanti, D. I. dkk. (2013). Sintaksis bahasa Indonesia. Tanggerang: Pustaka Mandiri.

Tarigan, H. G. (2008). Berbicara: sebagai suatu keterampilan berbahasa. Bandung: Angkasa.

Widjono Hs. (2012). Bahasa Indonesia. Jakarta: Grasindo. 